\title{
Rhododendron simsii poisoning in goats in Southern Brazil
}

\author{
Intoxicação por Rhododendron simsii em caprinos no Sul do Brasil
}

\author{
Sérgio Farias Vargas Junior ${ }^{\mathrm{I}}$ Clairton Marcolongo-Pereira ${ }^{\mathrm{I}}$ Dênis Halinski-Silveira ${ }^{\mathrm{I}}$ \\ Fabiane Borelli Grecco ${ }^{I}$ Margarida Buss Raffi ${ }^{I}$ \\ Ana Lucia Schild ${ }^{\mathrm{II}}$ Eliza Simone Viégas Sallis ${ }^{\mathrm{I}^{*}}$
}

- NOTE -

ABSTRACT

This study describes the natural poisoning of goats by Rhododendron simsii in Southern Brazil. Five of eight goats died after ingesting branches of plants, which were pruned and placed near the goats. Clinical signs observed were restlessness, shrill bleating, profuse regurgitation, looking and kicking at the flank, a loss of balance, irregular gait, staggering, and opisthotonos. At necropsy or histopathology affected goats had not showed lesions. Two goats were fed with $21.5 \mathrm{~g} \mathrm{~kg}^{-1} \mathrm{bw}$ and $30 \mathrm{~g} \mathrm{~kg}^{-1} \mathrm{bw}$ of fresh leaves of R. simsii. Both goats developed signs similar to those naturally affected goats. These findings indicated that $\boldsymbol{R}$. simsii is highly toxic and lethal to goats.

Key words: Rhododendron simsii, grayanotoxins, azalea, poisoning, goats.

RESUMO

Descreve-se um surto de intoxicação espontânea por R. simsii em caprinos no sul do Brasil. Cinco de oito cabras morreram após a ingestão da planta que foi podada e colada no local onde estavam os caprinos. Os sinais clínicos caracterizamse por excitação, balidos estridentes, regurgitação, coicear o flanco, desequilíbrio e opistótono. Não foram observadas lesões macroscópicas e histológicas nos animais necropsiados. Dois animais receberam doses de 21,5 e $30 \mathrm{~g} \mathrm{~kg}^{-1}$ de folhas verdes de $\boldsymbol{R}$. simsii. Ambos desenvolveram sinais clínicos similares aos animais intoxicados espontaneamente. Esses achados indicam que $\boldsymbol{R}$. simsii é altamente tóxica e letal para caprinos.

Palavras-chave: Rhododendron simsii, grayanotoxinas, azaleia, intoxicação, caprinos.

The genus Rhododendron, Ericaceae family, is an ornamental shrub popularly known as azalea. The plant has deciduous or semi-deciduous leaves and produces white or colored flowers in autumn and winter (ARMIÉN et al., 1995). Many of the Ericaceae family members produce diterpenoid grayanotoxins. These compounds bind to the sodium channels in cell membranes and increase permeability to sodium ions in excitable membranes. Excitable cells (nerve and muscle) are maintained in a state of depolarization, during which the entry of calcium into the cells may be facilitated. All of the observed responses of the skeletal and heart muscles, nerves, and central nervous system are related to the membrane effects (PUSCHNER et al., 2001).

Spontaneous poisoning cases generally occur in the winter, when the plant is green and when other forages have dried up and are depleted. Accidental poisoning occurs when prunings or clippings are discarded within reach of animals (CASTEEL \& WAGSTAFF, 1989). Poisoning in humans has been associated with the consumption of "mad honey", or honey containing grayanotoxin; Labrador tea; cigarettes; and various decoctions used in alternative medicine (JANSEN et al., 2012). In contrast to poisoning in humans, intoxications in cattle lead to death in most cases (POPESCU \& KOPP, 2013).

R. simsii poisoning has not been previously described in humans, and reports in livestock are rare. However, poisoning by other Rhododendron spp. is more common and has been described in goats

\footnotetext{
IFaculdade de Veterinária (FV), Universidade Federal de Pelotas (UFPel), Campus Universitário, Prédio 1, 96010-900, Pelotas, RS, Brasil. E-mail: esvsallis@yahoo.com.br.*Autor para correspondência.

"Laboratório Regional de Diagnóstico, FV, UFPel, Pelotas, RS, Brasil. 
(PUSCHNER et al., 2001; PEREIRA et al., 2008), sheep (CASTEEL \& WAGSTAFF, 1989; BLACK, 1991), alpacas (CRAWFORD, 1999) and llamas (MILLER, 1981). Experimentally, poisoning with $\boldsymbol{R}$. ledifolium has been reproduced in sheep and cattle (ARMIÉN et al., 1995) and poisoning with $\boldsymbol{R}$. indicum has been replicated in cattle (TOKARNIA et al., 1996).

Clinical signs begin between several hours and one day following ingestion of the plant (CASTEEL \& WAGSTAFF, 1989). The observed signs are depression, severe drooling, vomiting, abdominal pain, tachycardia, dyspnea, weakness, muscle tremors, moaning, ataxia, recumbency, and opisthotonos (ARMIÉN et al., 1995; PEREIRA et al., 2008). Gross lesions are nonspecific, and serous bleeding in the intestines, and aspiration pneumonia in two animals (CASTEEL \& WAGSTAFF, 1989; ARMIÉN et al., 1995) were observed.

This report describes intoxication in goats that were accidentally poisoned by $\boldsymbol{R}$. simsii in Southern Rio Grande do Sul, Brazil. In September 2009, on a farm in the municipality of Pelotas, five male and three female 3- to 5-year-old mixedbreed goats were kept in a native grass pasture. Five animals were intoxicated after ingesting $\boldsymbol{R}$. simsii (Figure 1) branches that were pruned and placed near the goats. The animals ingested the leaves and flowers in the early afternoon. Five hours after ingestion, the goats developed clinical signs characterized by restlessness, shrill bleating, profuse regurgitation, colic, looking and kicking at the flank, a loss of balance, irregular gait, staggering, and opisthotonos. The following morning, five of the eight animals had died. Three goats were necropsied, and no macroscopic lesions were observed. Samples of skeletal muscle, heart (right atrium, right papillary muscle, right free ventricular wall, septum, left atrium, left papillary muscle, and left ventricular free wall), brain, spinal cord, lung, liver, kidney, adrenal gland, urinary bladder, thyroid gland, lymph node, esophagus, rumen, omasum, abomasum, duodenum, pancreas, jejunum, ileum, cecum, and colon, were collected and fixed in $10 \%$ neutral buffered formalin. Tissues were processed, sectioned at $5 \mu \mathrm{m}$ and stained using standard histologic techniques. The plant was identified at the Department of Botany - UFPel.

Green $\boldsymbol{R}$. simsii leaves and branches were collected and fed immediately to two goats at a single dose of $21.5 \mathrm{~g} \mathrm{~kg}^{-1}$ and $30 \mathrm{~g} \mathrm{~kg}^{-1}$ based on the doses used by TOKARNIA et al. (1996). Approximately 2 hours after administration of the plant, both goats exhibited clinical signs identical to those described in the accidental poisoning. This clinical progression was initially characterized by regurgitation of rumen contents, hypersalivation, restlessness, and abdominal pain. Later, the goats developed shrill bleating, incoordination, and difficulty in standing and ultimately became sternally recumbent. The goats were unable to lift their heads and had opisthotonos, nystagmus, and bruxism. The animal that received a high dose died 33 hours after the start of the experiment. No macroscopic or histological changes of pathological significance were observed.

On day 4 of the experiment, goat 1 remained in sternal recumbency. The goat showed gradual improvement and recovered 7 days after administration

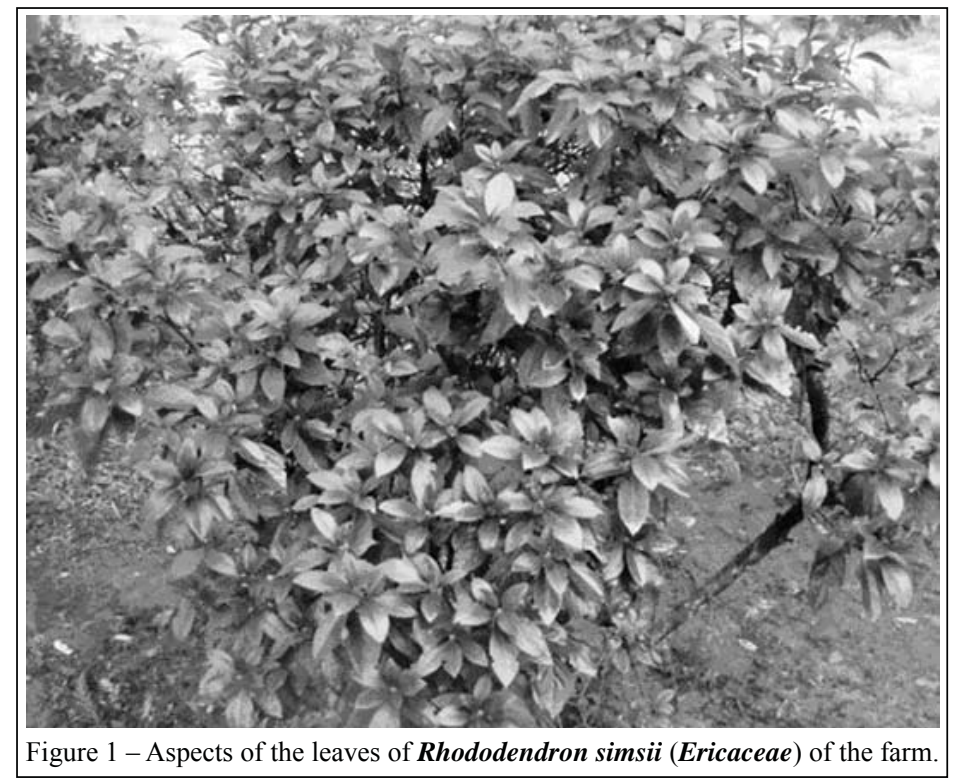

Ciência Rural, v.44, n.7, jul, 2014. 
of the plant. A diagnosis of $\boldsymbol{R}$. simsii toxicosis was made based on epidemiological data, clinical signs, a lack of gross and histologic lesions suggestive of other diseases, and the experimental reproduction of the disease in the same affected specie.

Poisoning by $\boldsymbol{R}$. simsii in ruminants is rare (TOKARNIA et al., 2012) and many cases are accidental, occurring when clipped branches are thrown into paddocks. Certain plants invade pastures, but this phenomenon is less common, and consequently, freeranging animals rarely are poisoned.

Poisoning by $\boldsymbol{R}$. macrophyllum, $\boldsymbol{R}$. ponticum, and $\boldsymbol{R}$. indicum has been described in goats and sheep (CASTEEL \& WAGSTAFF, 1989; BLACK, 1991). In Brazil, there has been only one description of the poisoning of goats by Rhododendron spp., although the plant species involved were not identified (PEREIRA et al., 2008).

In the present report, no macroscopic lesions were observed. However, in a study on Rhododendron spp., during necropsy, severe pulmonary congestion and edema, and abdominal visceral congestion were observed (ZHIHONG, 1994). Histopathologically, congestion, hemorrhage, degeneration, and focal necrosis were observed in the kidney, liver, heart, small intestine and the central nervous system. These changes may be due to differences between the toxicities of Rhododendron spp.

The mortality rate of $\boldsymbol{R}$. simsii toxicosis reported here was high $(62.5 \%)$. In previous cases of Rhododendron intoxication in sheep and goats, the reported mortality rates were $18 \%$ and $11 \%$, respectively (SHANNON, 1985; CASTEEL \& WAGSTAFF, 1989). The high mortality rate observed in the present study may have been due to the ingestion of large amounts of the plant by the goats in a short period of time. In addition, the intoxication occurred in late winter, with a lack of forage.

Experimentally, the lethal dose of Rhododendron spp. is variable, occasionally exceeding $1000 \mathrm{mg} / \mathrm{kg}$ in mice using $\boldsymbol{R}$. anthopogon. The lethal dose is 5.1 and $4.9 \mathrm{mg} \mathrm{kg}^{-1}$ using extracts of $\boldsymbol{R}$. brachycarpum and $R$. metternichii var. pentamerum, respectively, in rats (POPESCU \& KOPP, 2013); $29.4 \mathrm{~g} \mathrm{~kg}^{-1}$ using $\boldsymbol{R}$. indicum in cattle (TOKARNIA et al., 1996); and $15 \mathrm{~g} \mathrm{~kg}^{-1}$ using $\boldsymbol{R}$. ledifolium in sheep (ARMIÉN et al., 1995). In this study, R. simsii was lethal at dose of $30 \mathrm{~g} \mathrm{~kg}^{-1}$ bw and produced clinical signs of intoxication, with recovery within 7 days, at a dose of $21.5 \mathrm{~g} \mathrm{~kg}^{-1}$ bw. This finding suggests that this plant's toxicity varies between different species.

Many compounds have been isolated from different Rhododendron spp. Diterpenoids represent the second most prevalent chemical class of the genus, and most compounds are grayane-type and account for plant toxicity (POPESCU \& KOPP, 2013). A grayane-type toxin was most likely involved in the intoxication reported here.

The clinical signs observed in goats in this experiment were similar to the signs reported in other cases of Rhododendron spp. poisoning in ruminants (CASTEEL \& WAGSTAFF, 1989; PUSCHNER et al., 2001). The clinical signs suggest that the grayanotoxins observed in plants of the genus Rhododendron act on the central and peripheral nervous systems (ONAT et al., 1991). The gastrointestinal, cardiovascular, and respiratory signs indicate that the toxin in the plants causes changes in the visceral efferent system of the lower motor neurons. The neuromuscular signs indicate an involvement of the somatic efferent system of the lower motor neurons (ARMIÉN et al., 1995). The reflux of the rumen was very intense in the experimentally poisoned animals and should be considered as significant in the diagnosis of this toxicosis. The hypermotility of the rumen, resulting in the reflux of its content, is due to the action of the plants' grayanotoxin on the muscarinic and nicotinic cholinergic receptors (ARMIÉN et al., 1995).

Ornamental plants that induce similar disturbances in the gastrointestinal tract, such as Andromeda polifolia, Ledum spp. and Pieris spp. (PLUMLEE et al., 1992; KNIGHT, 2006;) and Nerium oleander (PEDROSO et al., 2009), should be included in the differential diagnosis. In the present study on $\boldsymbol{R}$. simsii in goats, there were no significant gross and microscopic alterations, similar to what was observed for cattle experimentally poisoned with $\boldsymbol{R}$. indicum (TOKARNIA et al., 1996).

Although poisoning by $\boldsymbol{R}$. simsii is not frequent in ruminants, the wide distribution of this ornamental plant in Brazil increases its potential for ingestion and poisoning, and measures should be taken to avoid the consumption of this plant.

\section{ETHICAL STATEMENT}

We declare to whom correspond that we assume any responsibility about any process realized during the development of the research entitled Rhododendron simsii (Ericaceae) Planch. poisoning in goats in Southern Brazil. Likewise we are available to answer any questions that may be needed.

\section{REFERENCES}

ARMIÉN, A.G. et al. Intoxicação experimental por Rhododendron ledifolium (Ericaceae) em ovinos. Pesquisa Veterinária Brasileira, v.15, n. 1, p.1-9, 1995. 
BLACK, D.H. Rhododendron poisoning in sheep (Correspondence). Veterinary Record, v.128, p.363-364, 1991.

CASTEEL, S.; WAGSTAFF, J. Rhododendron macrophyllum poisoning in a group of goats and sheep (Toxic Plant Case Reports). Veterinary and Human Toxicology, v.31, p.176-177, 1989.

CRAWFORD, J.E. Rhododendron in poisoning in alpacas (Correspondence). Veterinary Record, v.144, n.24, p.680, 1999.

JANSEN, S.A. et al. Grayanotoxin poisoning: 'mad honey disease' and beyond. Cardiovascular Toxicology, v.12, n.3, p.208-215, 2012. Available from: <http://www.ncbi.nlm.nih.gov/pmc/articles/ PMC3404272/>. Accessed: Nov. 9, 2013. doi: 10.1007/s12012012-9162-2.

KNIGHT, A.P. A guide to poisonous house and garden plants. Jackson WY: Teton NewMedia, 2006. 324p.

MILLER, R.M. Azalea poisoning in a llama: a case report. Veterinary Medicine, Small Animal Clinician, v.76, n.1, p.104, 1981.

ONAT, F. et al. Site of action of grayanotoxins in mad honey in rats. Journal of Applied Toxicology, v.11, n.3, p.199-201, 1991.

PEDROSO, P.M.O. et al. Intoxicação natural e experimental por Nerium oleander (Apocynaceae) em bovinos no Rio Grande do Sul. Pesquisa Veterinária Brasileira, v.29, n.5, p.404-408, 2009. Available from: $<$ http://www.scielo.br/scielo.php?script=sci arttext\&pid=S0100-736X2009000500008>. Accessed: Nov. 9, 2013. doi: http://dx.doi.org/10.1590/S0100-736X2009000500008.

PEREIRA, E.C. et al. Intoxicação por azaléia (Rhododendron spp) em dois caprinos. In: LATIN AMERICAN VETERINARY
CONFERENCE, 2008, Lima, Peru. Proceedings of the Latin American Veterinary Conference. Available from: $<\mathrm{http}: / / \mathrm{www}$. ivis.org/home.asp>. Accessed: Jul. 15, 2013.

PLUMLEE, K.H. et al. Japanese pieris toxicosis of goats. Journal of Veterinary Diagnostic Investigation, v.4, p.363-364, 1992. Available from: <http://vdi.sagepub.com/content/4/3/363.full.pdf $>$. Accessed: Nov. 9, 2013.

POPESCU, R.; KOPP, B. The genus Rhododendron: an ethnopharmacological and toxicological review. Journal of Ethnopharmacology, v.147, n.1,p.42-62,2013. Available from: $<$ http:// www.sciencedirect.com/science/article/pii/S0378874113001177>. Accessed: Nov. 9, 2013. doi: http://dx .doi.org/10.1016/j. jep.2013.02.022.

PUSCHNER, B. et al. Grayanotoxin poisoning in three goats. Journal of the American Veterinary Medical Association, v.218, n.4, p.527-528, 2001. Available from: <http://avmajournals. avma.org/doi/abs/10.2460/javma.2001.218.573>. Accessed: Nov. 9, 2013. doi: 10.2460/javma.2001.218.573.

SHANNON, D. Rhododendron poisoning in sheep. Veterinary Record, v.116, n.16, p.451, 1985.

TOKARNIA, C.H. et al. Estudo experimental sobre a toxidez de algumas plantas ornamentais em bovinos. Pesquisa Veterinária Brasileira, v.16, p.5-20, 1996.

TOKARNIA, C.H. et al. Plantas tóxicas do Brasil para animais de produção. 2.ed. Rio de Janeiro: Helianthus, 2012. 586p.

ZHIHONG, H. A study on the toxicity of azalea to goats. Journal of Southwest National College, v.20, p.1-5, 1994. 